Мосов С. П., д.військ.н., професор ${ }^{1}$; Хорошилова С. Й. ${ }^{2}$

1 - Національний авіаційний університет, Київ;

2 - Національний університет оборони України імені Івана Черняховського, Київ

\title{
Особливості застосування тактичної безпілотної розвідувальної авіації у воснних конфліктах
}

Резюме. На основі аналізу досвіду війн і локальних конфліктів досліджено та ідентифіковано особливості, умови та проблемні питання застосування тактичної безпілотної розвідувальної авіації.

Ключові слова: безпілотна авіація; розвідка; воєнний конфлікт.

Постановка проблеми. Результати аналізу широкого спектру завдань повітряної розвідки та спостереження, що вирішувалися із застосуванням тактичної безпілотної розвідувальної авіації, викликали необхідність у систематизації умов, особливостей i проблемних питань іiі застосування під час воєнних конфліктів.

\section{Аналіз останніх досліджень i} публікацій. Питаннями, пов'язаними із різноманітними дослідженнями щодо застосування безпілотних авіаційних комплексів (далі - БПАК) для вирішення завдань розвідки та спостереження, займалася низка українських та іноземних фахівців i вчених: М. Антонов, I. Величко, I. М. Даценко, М. Догерті, С. М. Ганін, Ю. К. Зіатдінов, І. С. Руснак, О. В. Карпенко, Ю. В. Коцуренко,

I. В. Матала,

О. М. Матусевич, С. П. Мосов, С. С. Невгад, Ю. М. Пащук,

С. А. Станкевич,

О. В. Харченко,

Ю. П. Сальник,

В. П. Харченко,

А. Л. Фещенко,

С. М. Чумаченко та ін. Разом з цим, питання виявлення та ідентифікації умов, особливостей i проблемних питань застосування тактичної безпілотної розвідувальної авіації у воєнних конфліктах потребує проведення досліджень досвіду таких конфліктів на системній основі.

Мета статті. Систематизувати умови, особливості та проблемні питання застосування тактичної безпілотної розвідувальної авіації під час воєнних конфліктів.

Виклад основного матеріалу. Однією 3 характерних рис воєнних конфліктів кінця XX - початку XXI століть стало ведення бойових дій підрозділами регулярної армії проти слабо організованих загонів і груп. Бойові дії все частіше велись без чітко визначеної смуги фронту в умовах гірсько- лісистої місцевості або в міських умовах, де спостереження 3 повітря було значно ускладненим. Основною бойовою одиницею в операціях проти малочисельних мобільних угруповань противника були тактичні підрозділи до бригади включно. Швидкоплинність обстановки, яка супроводжувала бойові дії під час конфліктів, вимагала наявності у командирів цих рівнів оперативних розвідувальних даних про місцезнаходження, стан і діяльність основних об'єктів противника. У таких умовах актуальності набували невеликі за розмірами мобільні безпілотні літальні апарати (далі БпЛА), які забезпечували розвідку об'єктів противника в тактичній глибині в масштабі реального часу в інтересах командирів рівня “взвод-батальон-бригада" [1].

Одні 3 перших відчули необхідність застосування розвідувальних БпЛА тактичного рівня російські військові. Це сталося під час бойових дій на території Чеченської республіки, які відбулися в період $1994-$ 1996 pр., а згодом у $1999-2003$ рр., і набули назви Першої та Другої чеченських воєн [2].

Перша війна в Чечні тривала біля двох років з 11 грудня 1994 р. до 31 серпня 1996 р. i в 14 разів перевищувала тривалість війни у зоні Перської затоки 1991 р. Не дивлячись на це, збройними силами Російської Федерації було використано тільки один тип БпЛА - "Пчела1T” (для порівняння, під час конфлікту в Іраку приймали участь 5 типів БпЛА) [3]. До складу комплексу входили два наземні пункти дистанційного управління з розташованими на них ПУ і 10 БПЛА “Пчела-1Т”, оснащених телевізійною апаратурою. Основними розвідувальними завданнями БпЛА у першій чеченській війні був пошук i виявлення терористів, маршрутів їхнього руху i перевалочних баз $[1,4]$. 
Друга війна, яка розпочалася 4 серпня 1999 р., мала на меті очищення території Дагестану від ісламських бойовиків, які вторгнулися 3 території Чечні. Основною формою збройної боротьби у воєнній кампанії 1999 - 2003 рр., вперше у військовій практиці, стала розвідувально-вогнева операція (далі PBO), головну роль в якій відігравали розвідувальні безпілотники.

Результати застосування БпЛА в Чечні змінили погляди більшості військового керівництва ЗС Росії на роль безпілотної авіації в сучасній війні. Це сталося завдяки тому, що засоби наземної розвідки, на які головним чином покладались російські військові при добуванні інформації про місцезнаходження об' єктів ураження, не виправдали надій. В умовах гірсько-лісистої місцевості Кавказу, коли підрозділам регулярної російської армії протистояли невеликі за чисельністю мобільні бандугруповання, можливості існуючих російських наземних засобів радіолокаційної та оптико-електронної розвідки були обмежені дальністю прямої видимості і не забезпечували виявлення цілей i об' єктів противника, що знаходились за природними укриттями. А ця інформація була край необхідна, у першу чергу, для наземних засобів ураження. Таких недоліків не мала безпілотна авіація, через що роль головного джерела розвідувальних даних про об'єкти ураження почали відігравати БпЛА.

Масового застосування БПЛА в Чечні так і не набули. Інформація, яка видавалась споживачам, була не досить якісною та своєчасною. Слід також відзначити низьку надійність (особливо в холодний період) БпЛА "Пчела-1Т" та його занадто скромні технічні характеристики. Так, якщо планер, двигун БпЛА i значна частина наземного обладнання ще відповідали вимогам, що до них пред'являлися, то телевізійна камера i частина електроніки були досить застарілими. Крім того, апарату була потрібна інфрачервона камера для виконання нічних польотів. Потребував збільшення i ресурс літальних апаратів, а також тривалість їх перебування в повітрі. Не останню роль у зниженні ефективності БпЛА "Пчела-1Т" відігравала його акустична помітність.

Шляхом усунення виявлених під час бойових дій недоліків рухались у наступному російські розробники, які на підставі досвіду застосування БпЛА в чеченській компанії створили модифікацію БпЛА "Пчела-1Т" “Пчела-ПМ”. Ресурс апарату був збільшений у
15 разів - до 150 польотів. Розвідувальна апаратура виконана в модульних змінних комплектах, що давало змогу вирішувати різні завдання у будь-який час доби.

Аналізуючи результати розвідувального забезпечення бойових дій на Кавказі, слід визнати, що одним з головних недоліків у діях російської армії було те, що значна частина воєнного керівництва, не розуміючи можливості розвідувальних БпЛА, продовжувала працювати за “застарілими” правилами - використовувати пілотовану розвідувальну авіацію та сили наземної розвідки. Але, навіть незважаючи на це, чеченський досвід визначив переваги БпЛА над іншими засобами розвідки, зокрема, у контртерористичних операціях. За допомогою безпілотників вдалося значно знизити рівень людських втрат, забезпечити пошук i виявлення терористів, здійснювати своєчасну передачу даних про терористів, а також їхні дії антитерористичним центрам, виявляти маршрути руху і перевалочні бази терористів.

Разом 3 тим, позитивні сторони БпЛА практично так і залишилися не витребуваними у ході Чеченських компаній. Причиною тому стала відсутність на озброєнні російської армії достатньої кількості сучасних БпАК та застаріла система управління i збору розвідувальних даних, до якої звикло російське військове керівництво.

На відміну від російських військових, значно активніше застосовувалися тактичні БпЛА збройними силами США, провідних країн НАТО та Ізраїлю. У збройних силах США ініціатором застосування тактичних БпЛА виступила морська піхота. Незважаючи на позитивні якості, які безумовно мали БпЛА Pioneer, американські морські піхотинці потребували більш легкого і мобільного БпЛА. У 1988 р. такий апарат під назвою Exdrone був створений, але тільки у Перській затоці у 1991 р. у ході операції "Буря в пустелі" ці БПЛА пройшли перші бойові випробування [5].

Крім БпЛА Exdrone в конфлікті з Іраком американськими військами використовувалися тактичні розвідувальні БПЛА Pointer. Полегшені апарати вагою 3,6 кг у легких алюмінієвих футлярах переносились у ранцях $\mathrm{i}$ збиралися в польових умовах. БпЛА, що мали радіус дії 4,8 км і були розраховані на роботу в повітрі протягом 1 год., використовувались для викриття наземних об'єктів противника безпосередньо уздовж лінії бойового зіткнення. Апарати були обладнані телекамерою для ведення розвідки у денний час, а також інфрачервоною апаратурою для роботи у 
темний час доби. Відеоінформація з борту БпЛА в чорно-білому зображенні передавалась на наземні пункти управління [3].

Ефективність дій безпілотних апаратів Pointer, які, у першу чергу, призначались для ведення розвідки на малій висоті, знижувалася через несприятливі умови пустельної місцевості Іраку, що не мала потрібних орієнтирів. У зв'язку з цим почала вивчатись можливість оснащення БпЛА приймачем глобальної супутникової системи навігації (GPS) і приладом нічного бачення.

Недоліками БпЛА Pointer i Exdrone за досвідом їх застосування в Іраку, за поглядами фахівців, стала залежність від метеоумов i відсутність лазерних цілевказівників для підсвічення цілей. Незважаючи на це, фірмам, що випускали зазначені апарати, рекомендували активізувати розроблення апаратів аналогічного типу - більш легких, недорогих, оснащених засобами оптикоелектронної, радіаційної, хімічної та біологічної розвідки, а також засобами РЕП і лазерного підсвічення цілей $[1,6]$.

У результаті, протягом 1997-1998 рр. у морській піхоті пройшли модернізацію біля 30 БПЛА Exdrone, після чого вони були перейменовані у Dragon Drone. Апарат мав унікальні на той час можливості. По-перше, БпЛА був оснащений телекамерою та лазерним цілевказівником, що дозволяло використовувати його для наведення ударної авіації. По-друге, у разі необхідності на борту апарату розташовувались засоби РЕБ і РТР. БпЛА мав у два рази меншу дальність польоту ніж його попередник Exdrone (до 40 км), але цей недолік компенсувався розширеними розвідувальними можливостями БпЛА за рахунок збільшення номенклатури корисного навантаження. Як наслідок актуальності БпЛА 3 такими характеристиками - інтенсифікація виробництва цих апаратів у наступні роки. Всього було виготовлено біля 400 таких апаратів [3, 7].

Активно застосовувались у воєнному конфлікті в Іраку безпілотники Франції. Як вдалося встановити, чотири комплекси БпЛА MART базувалися на території Саудівської Аравії і забезпечували розвідку іракських об’єктів у радіусі до 100 км. Відеоінформація з БпЛА передавалась на наземну станцію по радіолінії на відстань до 30 км. До початку наступальних дій сухопутного компоненту багатонаціональних сил (далі - БНС) БпЛА діяли на висоті 300 м, але на цій висоті вони створювали небезпеку пілотованій авіації.
Тому, в наступному, у ході наступальної операції, для того щоб уникнути зіткнення 3 літаками БНС, висота їх бойового застосування була знижена до 150 метрів.

Серед основних недоліків БпЛА, які виявилися під час їх застосування, відмічалися малий час знаходження у повітрі та низькі розвідувальні можливості [6].

Позитивно оцінюючи дії розвідувальних систем на базі БпЛА у конфлікті в районі Перської затоки, військові все більше почали звертати увагу на доцільність використання БпЛА для забезпечення розвідувальною інформацією командирів підрозділів і частин, які безпосередньо беруть участь у бойових діях. Іншими словами, виникла необхідність прийняття на озброєння БпЛА найнижчого рівня “батальйон-рота-взвод”. Однак це рішення остаточно закріпилось тільки у другому періоді розвитку БпЛА, під час Балканської кризи.

У повітряній розвідувальній операції “Око орла" над Балканами 3 жовтня 1998 р. повітряну розвідку вели три типи БПЛА тактичного рівня: від ВПС Великої Британії БПЛА Phoenix; від ВПС Франції - БпЛА Crecerelle; від ВПС Італії - БпЛА Mirach 26 [3].

Для БПЛА Франції це вже був другий після Іраку воєнний конфлікт. Досвід Іраку пішов на користь французьким військовим. Основні недоліки БпЛА MART, такі як малий час знаходження у повітрі та низькі розвідувальні можливості, були враховані і в 1994 p. фахівцями компанії Sagem був створений тактичний БПЛА Crecerelle. Новий апарат ніс значно більше корисного навантаження і міг у 1,5 рази довше (до 6 год.) знаходитись у повітрі. БпЛА був обладнаний панорамною відеокамерою, фотокамерою високої розрізненої здатності, інфрачервоними сенсорами, а також системою передачі даних до наземного оператора на відстань до 50 км. Основними завданнями, які виконувались безпілотниками, стали ведення спостереження за полем бою та проведення розвідувальних операцій у тактичній глибині.

Вперше БпЛА національної розробки використала Італія. Італійський контингент для виконання завдань цілодобового спостереження наземних об'єктів застосував безпілотні апарати Mirach 26. Це був апарат ближньої дії, його бойовий радіус складав всього 100 км. У той же час, БпЛА було обладнано комплектом сучасної розвідувальної апаратури, що давало змогу використовувати його для виявлення об' єктів у будь-який час доби, у тому числі й замаскованих. До складу 
бортового обладнання входили дві телевізійні камери 3 високою розрізненою здатністю (одна - для розвідки в денний час, друга - у нічний) і тепловізійна апаратура.

У липні 1999 р., коли повітряна операція на Балканах була майже закінчена, Армія Великої Британії вперше застосувала в Косово БПЛА Phoenix, основним завданням якого було ведення розвідки та спостереження за полем бою. Апарат надійшов на озброєння тільки у 1998 р., але вже тоді його не можна було назвати сучасним. Начебто високі характеристики апарату - мала візуальна, радіолокаційна, теплова й акустична помітність і змінний контейнер 3 сучасною розвідувальною апаратурою - під час бойових дій не підтвердились: найчисельніші втрати 14 ЛА 3 48, часта відмова розвідувального обладнання. А “бенефіс" прийшовся на 2003-й рік, коли в умовах сухого і жаркого клімату Іраку військові контингенту Великої Британії вимушені були зовсім відмовитись від цього БпЛА [1].

Високий рівень застосування розвідувальних БпЛА під час бойових дій в Югославії відповідним чином відбився на рівні їх втрат. Як вдалося встановити, перший БпЛА (Crecerelle) було збито вогнем противника 14 травня 1998 р. У цілому, загальні втрати склали 17 БпЛА - 14 Phoenix i 3 Crecerelle.

У 2000 р. військові фахівці Німеччини, які своєчасно врахували попередній досвід США та Франції, провели в Косово експериментальні випробування нового БпЛА Luna X-2000. Основними вимогами до БпЛА стали: можливість його використання цілодобово у будь-яких метеоумовах; компактність розміщення наземного обладнання (максимум на двох машинах); наявність автоматичної системи навігації, яка б давала змогу забезпечити політ БпЛА за спланованим маршрутом із можливостями внесення поправок за допомогою супутникової системи навігації GPS. Особливістю БпЛА було найсучасніше на той час розвідувальне обладнання - телевізійна камера відомої німецької фірми Zeiss, а також нова РЛС. БпЛА міг вести розвідку в радіусі 20 км протягом 4 годин. Незважаючи на це, БПЛА Luna так і не встиг довести власні переваги внаслідок закінчення воєнного конфлікту $[1,3]$.

Таким чином, конфлікт на Балканах остаточно закріпив висновок, зроблений під час першої компанії в Іраку про необхідність використання БПЛА в інтересах тактичних підрозділів.

На початок воєнної операції в Іраку 2003 р. такі БпЛА складали вже біля $80 \%$ загальної кількості безпілотних апаратів. Серед понад 100 одиниць БпЛА, які брали участь в операції “Свобода Іраку”, біля 80 одиниць були апарати тактичного рівня. Серед них 9 RQ7А Shadow 200, 20 БпЛА Dragon Еye; 28 БпЛА FPASS (варіант SentryOwl); 6 Sierra Foxe; i точно не встановлена кількість FQM151A Pointer, Raven i Phoenix. Втрати в операції склали всього 4\%: 2 БпЛА Shadow-200 i 2 БПЛА Phoenix [1, 4].

Для забезпечення розвідувальною інформацією органи тактичного управління вищих рівнів (бригада) в Іраку широко використовувались БпЛА Shadow-200. Це був перший бойовий досвід нових американських тактичних БпЛА. Shadow-200 був більш швидкісний, ніж його попередник Shadow-600, але меншого радіусу дії, і призначався для ведення розвідки та оцінки результатів ударів у бригадній ланці. Більшість польотів проводилися вночі. Апарат мав нову бортову РЛС, яка давала змогу виявляти рухомі цілі.

Командири батальйонного та ротного рівня морської піхоти США використовували в своїх інтересах в Іраку легкі переносні БпЛА Dragon Еуе. Міні-БПЛА Dragon Еуе вагою всього 2 кг використовувались для ведення розвідки та спостереження за обстановкою протягом 1 год. у будь-який час доби в радіусі до 10 км. Безпілотники швидко монтувалися протягом 10 хв. і запускалися прямо з руки, що робило їх незамінними в умовах швидкозмінної обстановки. У той же час, можливість перебування безпілотника в повітрі протягом всього однієї години не задовольняла морську піхоту.

Незважаючи на те, що в Іраку більшість БпЛА діяли в інтересах американського контингенту, на Південному сході країни в зоні відповідальності Великої Британії активно використовував безпілотну авіацію британський контингент. Це були БпЛА Phoenix, уже відомі по конфлікту на Балканах. БпЛА, які були розроблені для виконання завдань спостереження в Північній i Центральній Європі, під час конфлікту 1999 р. у Югославії показали свою низьку ефективність і надійність. А в умовах високих температур повітря в Іраку БпЛА Phoenix виявилися зовсім непридатними до використання. Внаслідок такого стану із засобами повітряної розвідки в Іраку керівництво британських підрозділів 
потребувало інших, більш ефективних, типів БпЛА. Вибір випав на комплекс безпілотної розвідки на базі малогабаритного американського БпЛА Raven. Це був практично у двічі зменшений у габаритах варіант БпЛА Pointer. Але, на відміну від БпЛА Pointer, Raven, мав більшу тривалість польоту (до 1,2 год.) і більш сучасне розвідувальне обладнання, у тому числі й апаратуру ІЧ-діапазону, яка давала змогу виявляти замасковані об'єкти та вести розвідку вночі.

У цілому, застосування тактичних БпЛА в Іраку під час операції "Свобода Іраку" дозволило забезпечити вирішення більшості розвідувальних завдань в інтересах американо-британської коаліції. Проведений аналіз бойового досвіду безпілотної авіації в Іраку виявив зростання попиту на невеликі за розміром мобільні БпЛА.

Раніше (на Балканах у 1999 р. і в Іраку в 1991 р.) БПЛА використовувались переважно для виконання розвідувальних завдань над великими за розмірами територіями [8]. У період, коли бойові дії перейшли на міські вулиці, існуючі на озброєнні військового контингенту в Іраку БПЛА вже не змогли ефективно виконувати завдання, які на них були покладені. Міська інфраструктура та великі забудови перешкоджали не тільки безпосередньо польоту БпЛА, а й процесу управління їм. Крім того, значні труднощі визивав процес передачі розвідувальної інформації, зокрема відеозображення, у масштабі реального часу [6]. Невеликі озброєні угруповання, що діяли в міській місцевості, пристосувалися до розвідувальних польотів БпЛА, заздалегідь реагували на звук апарату, що наближався, бачили його візуально, після чого зникали в багаточисельних будівлях. Необхідність маневреного, низькошвидкісного та малошумного БПЛА, здатного нести на собі датчики для виявлення противника, у тому числі і в середині будівель, сформувала нові вимоги до створення перспективних мініБПЛА.

Ще одним недоліком, виявленим за досвідом Іраку, стала низька оперативність надходження розвідувальних даних безпосередньо до військових підрозділів, що вели бойові дії в окремому секторі міста. Інформація, яка надходила, через швидкоплинність зміни обстановки при веденні бойових дій в умовах міста, була вже застарілою $[1,6]$.
Схожа на Ірак ситуація, коли в бойових діях проти невеликих терористичних угруповань командири найнижчого рівня "взвод-рота" потребували оперативної розвідувальної інформації, виникла в Афганістані. Серед нових БпЛА, які там використовувались, був i німецький розвідувальний БпЛА Aladin. Підрозділи бундесверу зі складу Міжнародних сил по сприянню безпеці в Афганістані розпочали його використання у березні 2003 р. Підставою для створення БпЛА Aladin стала необхідність використання малогабаритних апаратів із запуском $з$ руки, яких на той час на озброєнні Бундесверу не було [1].

БпЛА Luna, який німецький контингент випробував на Балканах у 2000 р., за своїми параметрами не підходив для виконання завдань антитерористичної операції в умовах Афганістану. Апарат вагою 30 кг запускався за допомогою катапульти, що значно обмежувало його мобільність, яка була дуже важливим критерієм. БпЛА Aladin мав вагу всього 3,5 кг і не потребував спеціальної стартової площадки. Запуск БпЛА здійснювала одна людина з руки, а посадку апарат виконував за допомогою парашуту. Електродвигун, що обертав пропелер, давав змогу розвивати швидкість 45-90 км/год. і патрулювати в повітрі до 30 хв. На борту БпЛА знаходилася відеокамера й апаратура для передачі даних на командний пункт.

Не звертаючи увагу на те, що країни НАТО здійснили стрімкий ривок у напрямку створення БпЛА, у першу чергу, завдяки участі ï контингентів у воєнних конфліктах на Балканах, в Іраку та Афганістані, першість у розвитку i застосуванню БпЛА тактичного рівня залишалась за Ізраїлем. Уже на початку XXI ст. на озброєнні ізраїльських підрозділів знаходилось понад 10 типів БпЛА тактичного рівня. Такої статистики не було у жодній країні світу. Важливо і те, що ці БпЛА активно закуповувались країнами НАТО, у першу чергу США, які застосовували їх у воєнних конфліктах.

Необхідність мати на озброєнні тактичні БпЛА була для ситуації, що склалася в Ізраїлі, безперечною. Тільки невеликий за розмірами, малошумний і тихохідний ЛА міг виконати завдання по пошуку терористів у міських умовах.

Для ведення повітряної розвідки на бригадному рівні ізраїльськими військовими використовувався БпЛА ближньої дії Mini-V. Апарат мав стартову вагу всього 55 кг і максимальну висоту бойового застосування 
4000 м. Він був оснащений сучасною розвідувальною апаратурою. Пуск БпЛА здійснювався пружинною системою з рейкової пускової установки, а посадка виконувалась за допомогою парашуту. Пускова установка розміщувалась на даху транспортної машини, з якої здійснювалося управління БпЛА.

Для ведення повітряної розвідки на рівні “взвод-батальон” і в інтересах сил спеціального призначення в Ізраїлі застосовувались міні-БпЛА. Одними з перших зразків таких апаратів став БПЛА Skylight-B. Апарат мав вагу всього 4,5 кг, запускався 3 руки і патрулював місцевість у радіусі 10 км на протязі 70 хв. Особливістю БпЛА було успішне застосування при несприятливих метеоумовах. Декілька систем Skylight-В були розгорнуті на рівні батальйонів і діяли в районах бойових дій в інтересах наземних військ.

Одним 3 конкурентів БПЛА Skylight-В став міні-БпЛА Skylark. Skylark мав у 1,5 рази більшу ніж Skylight-B тривалість польоту (2 год.) при практично такому ж радіусі. В апаратах довжиною 2 м і вагою всього 5,5 кг розташовувалось сучасне розвідувальне обладнання: три цифрові камери або три тепловизори, що давало змогу вести цілодобову розвідку, у тому числі й замаскованих об' єктів.

Як встановлено на підставі аналізу досвіду, у ході бойових дій ізраїльськими військовими застосовувалась велика кількість різноманітних безпілотників. А це створювало великі труднощі в їх експлуатації та логістичній підтримці, так як кожен тип БпЛА мав окрему наземну станцію управління та обробки інформації, власне бортове радіоелектронне та розвідувальне обладнання. Крім того, що ці елементи та системи мали особливості в обслуговуванні, власні запасні частини та контрольно-перевірочну апаратуру, кожен 3 апаратів вимагав спеціальної кваліфікації обслуговуючого персоналу. Все це призводило до великих фінансових i матеріальних витрат. Досвід воєнних конфліктів підтвердив, що для спрощення їх експлуатації в бойових умовах було би доцільно уніфікувати окреме обладнання і зробити його загальним для певного кола БпЛА. Такий крок дав змогу би не лише спростити логістичну підтримку та вирішити проблему перенавчання на нові типи БПЛА, а й зекономити кошти на нових розробках і спростити виробництво БпЛА. Одними 3 перших принцип уніфікації основних елементів запропонували i реалізували американці - для управління безпілотниками Shadow, Hunter і безпілотного вертольоту Fire Scout стала використовувалась єдина станція управління.

Ізраїльтяни запропонували свій різновид уніфікації - перехід до БпЛА модульної системи. Прикладом тому стала поява серії “легких" БпЛА, відомих під назвою I-View. БПЛА трьох розмірів зі злітною вагою 50, 125 і 250 кг, потребували меншої логістичної підтримки, ніж існуючі на той час БпЛА. Радіус ïх застосування становив від 50 до 150 км, тривалість перебування у повітрі - від 6 до 12 год, а корисне навантаження - від 8 до 41 кг. Усі версії використовували однакове програмне забезпечення [1].

Однією 3 переваг модульного підходу стала можливість легкої взаємозаміни датчиків. Зменшення ваги корисного навантаження давало змогу брати більший запас пального для збільшення дальності польоту.

Висновки. Таким чином, починаючи від конфлікту в районі Перської затоки 1991 р., набула розвитку тенденція використання розвідувальних БПЛА в інтересах найнижчих ланок військового управління “взвод-ротабатальон”. При цьому, чим нижче рівень підрозділу, тим меншим за розмірами $\mathrm{i}$ мобільнішим був БпЛА. БпЛА тактичного рівня, у більшості випадків, стали єдиним засобом розвідки, який забезпечував тактичні підрозділи інформацією про противника й об'єкти в масштабі реального часу. У результаті, командири змогли оперативно реагувати на зміни обстановки, що підвищило результативність дій їх підрозділів.

Подальші дослідження мають відбуватися за такими напрямами, як розвиток тактики застосування безпілотників у різних умовах ведення бойових дій, удосконалення системи підготовки фахівців 3 безпілотної авіації за всією лінійкою спеціальностей; зменшення помітності БпЛА для протиповітряних засобів знищення противника тощо.

\section{СПИСОК ВИКОРИСТАНОЇ ЛІТЕРАТУРИ}

1. Застосування безпілотних літальних апаратів у воєнних конфліктах сучасності / Ю. К. Зіатдінов, М. В. Куклінський, С. П. Мосов, А. Л. Фещенко та ін.; під ред. С. П. Мосова. - К.: Вид. дім "КиєвоМогилянська академія", 2013. - 248 с.

2. Мосов С. П. Розвідка у сучасних воєнних конфліктах за досвідом іноземних країн: [монографія] / О. А. Ільяшов, С. П. Мосов. - К., 2011. $-280 \mathrm{c}$.

3. Мосов С. П. Беспилотная разведывательная авиация стран мира: история создания, опыт 
боевого применения, современное состояние, перспективы развития: [монография] - К.: Изд. дом “РУМБ”, 2008. - 160 с.

4. Беспилотные летательные аппараты / [С. М. Ганин, А. В. Карпенко, В. В. Колногоров, Г. Ф. Петров]. - Санкт-Петербург: Невский бастион, 1999. - 162 с.

5. Мосов С.П. Аэрокосмическая разведка в современных военных конфликтах: [монография] / С. Мосов. - К.: Изд. дом “РУМБ”, 2008. - 248 с.

6. Аерокосмічна розвідка в локальних війнах сучасності: досвід, проблемні питання і тенденції: [монографія] / [Л. М. Артюшин, С. П. Мосов, Д. В. П'ясковський, В Б. Толубко]. К.: НАОУ, 2002. - 202 c.

7. Догерти, М. Дроны. Первый иллюстрированный путеводитель по БПЛА / М. Догерти; пер. с англ. В. Бычковой, Д. Евтушенко. - М.: Изд-во “Э”, 2017. - 224 c.

8. Мосов С. П. Разведывательный натиск в операции "Союзническая сила" / С. П. Мосов, С. И. Хорошилова // Волонтер. - 2008. - №.3 C. 4-10.

Стаття надійшла до редакції 30.10.17

Мосов С. П., д.воен.н., профессор ${ }^{1}$;

Хорошилова С. И. ${ }^{2}$

1 - Национальный авиационный университет, Київ;

2 - Национальный университет обороны Украины имени Ивана Черняховского, Киев

\section{Особенности применения тактической беспилотной разведывательной авиации в военных конфликтах}

Резюме. На основе анализа опыта войн и локальных конфликтов исследованы и идентифицированы особенности, условия и проблемные вопросы применения тактической беспилотной разведывательной авиации.

Ключевые слова: беспилотная авиация; разведка; военный конфликт.

\section{S. Mosov, DsM, professor ${ }^{1}$;}

S. Khoroshilova ${ }^{2}$

1 - National Aviation University, Kyiv;

2 - The National Defence University of Ukraine named after Ivan Cherniakhovskyi, Kyiv

Specific use of tactical unmanned reconnaissance aviation in military conflicts

Resume. The specificities, conditions and problem issues on the use of tactical unmanned reconnaissance aviation has been analyzed and identified on the basis of the analysis of the military operations and local conflicts' experience.

Keywords: unmanned aviation; reconnaissance; military conflict. 